\title{
CSR as the Foundation for Responsible Business Management - Good Practices in the Area of Organizational Governance
}

\author{
Małgorzata Kuraś ${ }^{1}$ \\ ${ }^{1}$ Department of Management, Czestochowa University of Technology, Armii Krajowej 19, Czestochowa, Poland \\ Correspondence: Małgorzata Kuraś, Department of Management, Czestochowa University of Technology, Armii \\ Krajowej 19, Czestochowa, Poland. E-mail: malgorzata.kuras@wz.pcz.pl
}

Received: October 24, 2019

Accepted: November 15, 2019

Online Published: December 22, 2019

doi:10.5430/rwe.v10n4p78

URL: https://doi.org/10.5430/rwe.v10n4p78

\begin{abstract}
The concept of corporate social responsibility (CSR) undertaken in the paper is an extremely important element of management in modern enterprises. It has been gaining increasing recognition all over the world. Also in Poland, entrepreneurs are increasingly interested in conducting business oriented not only towards economic effects but also broadly understood social interests and ecology. Nowadays, responsible business management is long-term operations, leading to finding the solutions which are beneficial both for the enterprise and its employees, local community, cooperation partners, investors and other stakeholders. The application of CSR principles allows enterprises to conduct their business activity in compliance with the principles of sustainable development, which is significant for the future of the whole world. One of the issues of the concept of CSR is the issue of organizational governance. As a key element of CSR, it has an impact on proper functioning of other areas and provides correct and persistent implementation of the principles of social responsibility. The objective of the paper is to present the issues of social responsibility, particularly taking into account organizational governance and an attempt to analyze good practices implemented in this area in enterprises operating in Poland. The paper reviews the activities undertaken for the implementation and development of CSR in enterprises and the definition of organizational governance. The analysis of good practices introduced in enterprises in the area of organizational governance in 2011-2017 was carried out, divided into five categories (reporting, ethics, management, dialogue with stakeholders and compliance). The benefits, which were gained by enterprises due to the implementation of good practices, were also indicated. The presented analysis can become an inspiration for the application of the presented practices by enterprises planning to undertake activities under CSR.
\end{abstract}

Keywords: corporate social responsibility, organizational governance, good practices

\section{Introduction}

The idea of CSR has been arousing unflagging interest already for several decades (Carroll, 1999). Both the theoreticians of management and economic practitioners agree as to the constantly growing role of corporate social responsibility in the contemporary economic realities since, nowadays, the fact that the enterprise does not cause harm to the environment and is not burdensome for local communities is not enough. It is called upon to actively take responsibility for the local and global community, the environment and to engage in activities beneficial for them. These circumstances cause that the reputation of the company and its financial results are exposed to risk when customers negatively perceive its social activities (Gustafson, 2007). Although widely discussed, CSR is not clearly defined both in the corporate and academic environment (Carroll, 1999; Dahlsrud, 2008). One of the most frequently quoted definitions was formulated in the document - Green Paper: Promoting a European Framework for Corporate Social Responsibility developed by the European Commission. In accordance with it, CSR is the concept, according to which enterprises voluntarily take into account social and environmental aspects in their economic activities and in contacts with stakeholders. The records in Green Paper indicate the activities of enterprises in two dimensions: the internal and external ones. The first one includes socially responsible practices within the framework of human resources management, health and safety at work and abilities to adapt to changes. The external dimension refers to the local community, trading partners, suppliers, customers and the issues of respect for human rights (Commission of the European Communities, 2001).

As a part of further work on the development of the CSR policy, the European Commission presented the renewed 
EU strategy concerning social responsibility. It proposed a new definition, according to which CSR was defined directly as "the responsibility of enterprises for their impact on society" (European Commission, 2011a, p. 6). The prerequisite to meet commitments resulting from this responsibility is respect for applicable legislation and collective agreements between social partners. In order to fulfill these commitments, enterprises should have a mechanism for integration of social, environmental, ethical issues and those related to human rights, as well as consumer problems, with their operations and core strategy, in close cooperation with stakeholders, to:

- maximize the creation of shared values for their owners/shareholders and other stakeholders and the society as a whole;

- $\quad$ recognize, prevent and mitigate their possible negative effects (European Commission, 2011a).

At the same time, it is emphasized that the maximization of the creation of shared values is favored by the long-term strategic approach towards CSR.

The principles of corporate social responsibility in relation to different areas of the activity of enterprises are also included in documents, such as: The Davos Manifesto (Steinmann, 1985), The Caux Round Table (The Caux Round Table), The Global Sullivan Principles (Alexis, 2010), The Initiative of the UN General Secretary of 1999 (United Nations Global Compact, 2015), OECD guidelines for multinational enterprises (OECD, 2011).

Wide-ranging debates and discussions concerning the issue of corporate social responsibility resulted in the adoption of the first international standard of social responsibility ISO 26000 Guidance on social responsibility in 2010 (ISO 26000:2010). ISO 26000 is not subjected to certification and it is designed for voluntary use by all entities, both private, public and non-profit organizations. This standard is aimed at helping organizations to contribute to sustainable development. It is to encourage to take socially responsible actions exceeding the adopted legal norms while acknowledging that obeying the law is the basic duty of each organization and it is the fundamental part of their social responsibility. The standard defines social responsibility as the responsibility of an organization for the impact of decisions and actions taken on the society and the environment through transparent and ethical behavior which (ISO/TMBG, 2010):

- brings about sustainable development, including health and welfare of the society,

- takes into account the expectations of stakeholders,

- is compliant with the law in force and international norms of behavior,

- functions in the whole organization and it is practiced within its sphere of influence.

Therefore, enterprises wishing to implement the concept of social responsibility ought to consider it in terms of the system approach. Most of all, it should correspond with and be taken into account in the vision of the company, its mission, strategic goals and the overall strategy. It should also be considered in the categories of the operation strategy which, most of all, includes the economic, ethical and environmental aspect (Kuraś, 2011).

In order to determine the scope of social responsibility, the aforementioned standard identifies its seven key areas: organizational governance, human rights, practices in the field of labor, the environment, fair operational practices, consumer issues and social commitment and local community development (ISO/TMBG, 2010). Although each of the listed areas includes a range of issues which contribute to the best possible implementation of the assumptions of CSR, the standard clearly indicates the specific role of organizational governance among them. It pinpoints that, admittedly, all the areas are related to each other and supplement each other, however, the effective and efficient organizational governance allows for taking actions within other key areas and implementing the principles of social responsibility.

Organizational or corporate governance "is a broad concept that has been used by regulators, investors, accountants, and boards of directors" (Hermanson and Rittenberg, 2003). OECD defines corporate governance as the network of relationships between the management staff of the company, its supervisory authorities, shareholders and other stakeholders. It also provides the structure through which the objectives of the company are established as well as it provides the methods for their achievement and opportunities for monitoring the results (OECD 2015).

Similarly, the concept of corporate governance was defined in Green Paper: The EU corporate governance framework. In accordance with this document, corporate governance is the system according to which enterprises are managed as well as a whole of relationships between the company's managers, its board, shareholders and other stakeholders (European Commission, 2011b). Corporate governance is considered as one of the ways to reduce harmful practices associated with adopting too short-term perspective and taking excessive risk. 
On the other hand, the aforementioned ISO 26000 standard uses the term of organizational governance which is defined as the system by means of which the organization takes and introduces decisions enabling the accomplishment of the objectives set. It consists of both formal management mechanisms resulting from specific structures and processes and informal mechanisms resulting from organizational culture (ISO/TMBG, 2010). In the context of CSR, organizational governance is acknowledged as the most important factor which allows the organization to take responsibility for the effects of the decisions and actions taken. It also combines social responsibility with the operation of the organization as a whole. An efficient system of organizational governance is also associated with the issue of motivating employees to act in accordance with the principles of social responsibility and include it in the culture of the organization (ISO/TMBG, 2010).

The objective of the paper is to present the issues of social responsibility, particularly taking into account organizational governance. In the study, it is attempted to analyze the actions taken by enterprises in this area and benefits resulting from their implementation.

\section{Materials and Methods}

For the purposes of the present paper, the desk research technique was utilized for the research, consisting in the analysis of the already available data and information (Bednarowska, 2015). The research activities included the analysis of operations in the area of responsible business taken by enterprises operating in Poland.

The research was carried out on the basis of the data included in the reports - "Responsible business in Poland. Good practices" developed by the association of Responsible Business Forum (Forum Odpowiedzialnego Biznesu, 2012; $2013 ; 2014 ; 2015 ; 2016 ; 2017$; 2018) They include the examples which, in the opinion of the report creators, best present the commitment of enterprises to the implementation of the principles of responsible business in Poland. Good practices are presented there in the areas of: organizational governance, human rights, practices in the field of labor, the environment, fair operational practices, consumer issues, social commitment and local community development. Enterprises report individual practices which they implement in the specific areas of CSR.

The subject of the analysis was the data for years 2011-2017. There was made the comparison of changes in the number of actions (good practices) taken in the field of organizational governance in subsequent years of the analyzed period, broken down by the categories under which these operations were carried out. There were also synthetically listed the examples of good practices introduced in enterprises and benefits resulting from their implementation.

\section{Results}

From the point of view of the subject matter of this paper, the analysis of the commitment of enterprises operating in Poland to the implementation of the principles of responsible business includes the practices in the area of corporate governance. The operations undertaken by organizations in this area are divided into five categories: reporting, ethics, management, a dialogue with stakeholders and compliance. The listing of the amount of the implemented operations in subsequent years of the analyzed period is presented in Table 1.

Table 1. The practices implemented under CSR by organizations operating in Poland in the field of organizational governance

\begin{tabular}{|c|c|c|c|c|c|c|c|c|c|}
\hline \multicolumn{10}{|c|}{$\mathrm{Y}_{\mathrm{Y}}$ Year } \\
\hline \multicolumn{10}{|c|}{$\begin{array}{l}\text { Categories } \\
\text { of practices }\end{array}$} \\
\hline \multicolumn{2}{|c|}{ Reporting } & 4 & 3 & 5 & 7 & 5 & 1 & 7 & 32 \\
\hline \multicolumn{2}{|c|}{ Ethics } & 4 & 11 & 13 & 15 & 15 & 5 & 11 & 74 \\
\hline \multicolumn{2}{|c|}{ Management } & 6 & 7 & 7 & 7 & 10 & 5 & 6 & 48 \\
\hline \multicolumn{2}{|c|}{$\begin{array}{l}\text { A dialogue with } \\
\text { stakeholders }\end{array}$} & 4 & 3 & 3 & 3 & 5 & 7 & 7 & 32 \\
\hline \multicolumn{2}{|c|}{ Compliance } & - & - & 3 & 3 & 1 & 1 & - & 8 \\
\hline \multirow[b]{2}{*}{ Total } & Practices & 18 & 24 & 31 & 35 & 36 & 19 & 31 & 194 \\
\hline & $\begin{array}{l}\text { Firms } \\
\text { (organizations) }\end{array}$ & 16 & 17 & 23 & 28 & 28 & 17 & 25 & \\
\hline
\end{tabular}

It should be pinpointed that the data presented in Table 1 relate to the amount of new practices implemented in 
subsequent years of the analyzed period. In addition to new operations, a significant part of enterprises included in the research continue the practices undertaken in previous years.

The analysis of the data included in Table 1 clearly indicates increasing involvement of organizations in the implementation of good practices in the area of organizational governance. A total of 194 activities were undertaken in the research period. Their number gradually increased from year to year whereas the climax, both in terms of the number of implemented practices and enterprises undertaking them, occurred in 2015 and, although in two subsequent years there were fewer practices implemented (especially in 2016), in the whole analyzed period, the upward trend was maintained. While analyzing the ratio of the number of enterprises to the number of operations undertaken, it can be seen clearly that some of companies are implementing more than one practice.

While analyzing the frequency of using the practices from the point of view of their categories one may immediately observe a significant number of operations in the field of ethics. Over seven years 74 practices were introduced in this category, which amounts to more than a third (slightly over 38\%) of all the implemented operations. The domination of practices in this group occurs practically every year. Such a high share of the activity in the field of ethics must be interpreted as particularly beneficial since the values included within this category are an extremely significant component of organizational governance. Standards and principles included in the created codes of ethics contribute both to building trust within the organization itself and to appropriate relationships with stakeholders outside. They are the support for employees in their work and constitute an integral part of organizational culture. An ethical and transparent way of conduct provides external stakeholders with security of cooperation, which consequently translates into broadly understood success of the organization.

Another category, as to the number of implemented practices, is management where 48 activities were undertaken. This amounts to nearly a quarter of all the practices implemented in the analyzed period (nearly $25 \%$ ). The practices undertaken within the category of 'management' are to create an efficient management system being the basis for organizational performance and to ensure the correct functioning of business processes. They are also to prevent the negative impact of the organization on the environment. A very important issue in this category, from the point of view of sustainable development, is building effective strategies of social responsibility allowing for combining the principal activity of the entity with social challenges.

"A dialogue with stakeholders" and "Reporting" are the categories in which the number of implemented practices was at the same level - 32 activities. In both categories there is a noticeable increase in new practices implemented by entities. This is the confirmation of the fact that the issue of transparency and credibility is increasingly important for enterprises. Due to the publication of reports, entities have an opportunity to inform on the conducted activity and its consequences and their actual commitment for the benefit of social responsibility. Creating reports is often preceded just by a dialogue with stakeholders by means of which it is possible to acquire information on their expectations and incorporate it in new strategies in the area of CSR. By 2017 the reporting on CSR had been a voluntary activity. On the other hand, one should expect an increase in operations related to reporting within the framework of CSR due to imposing such an obligation for the so called public interest entities since, in accordance with the EU Directive, the Accounting Act requires, in the framework of the activity report, to inform the aforementioned entities on the policy on environmental issues, social ones, employee matters, respecting human rights and anti-corruption.

The smallest, since only $4 \%$, share in the actions taken in the area of organizational governance, belongs to practices implemented in the category of "compliance". In the whole analyzed period, there were only 8 practices. Unfortunately, such a small share is not satisfactory since, within this category, there are undertaken operations aimed at ensuring the compliance of the functioning of the entity with legal provisions, standards, regulations voluntarily adopted by enterprises and ethical and moral standards.

The synthetic listing of the examples of practices implemented in the analyzed period by entities taking actions in the field of organizational governance and the benefits resulting from their implementation are presented in Table 2. 
Table 2. The examples of practices implemented in the field of organizational governance and the benefits resulting from their implementation

\begin{tabular}{|c|c|c|}
\hline $\begin{array}{c}\text { Categories of } \\
\text { practices }\end{array}$ & Examples of implemented practices & Benefits from implementation \\
\hline Reporting & $\begin{array}{l}\text { - reports in the field of CSR and sustainable } \\
\text { development (Sustainable development } \\
\text { reports, Social reports); } \\
\text { - integrated reports combining financial } \\
\text { reporting with CSR reporting, among others, } \\
\text { presenting relationships between financial and } \\
\text { non-financial aspects of activities of } \\
\text { enterprises; } \\
\text { - creating databases for reporting CSR data } \\
\text { (e.g. INDICIA database); } \\
\text { - implementing IT tools supporting the process } \\
\text { of reporting and monitoring non-financial data } \\
\text { (e.g. WebCSR system); } \\
\text { - conferences on creating CSR reports (among } \\
\text { others, the conference concerning the practice } \\
\text { of non-financial reporting in the context of } \\
\text { new requirements of the Accounting Act) }\end{array}$ & $\begin{array}{l}\text { - an opportunity to present all the activities } \\
\text { of the company in the field of CSR and } \\
\text { sustainable development; } \\
\text { - raising awareness on CSR and sustainable } \\
\text { development among employees and other } \\
\text { groups of stakeholders; } \\
\text { - an opportunity to assess the progress of the } \\
\text { company's operations on the way to } \\
\text { sustainable development and to determine } \\
\text { key objectives in this field; } \\
\text { - an opportunity to assess the impact of the } \\
\text { company's activity on society development, } \\
\text { the economy and natural resources. }\end{array}$ \\
\hline Ethics & $\begin{array}{l}\text { - introducing codes of ethical conduct (Codes } \\
\text { of Ethics, Codes of Good Practices, Ethical } \\
\text { Codes, Codes of Ethical Conduct); } \\
\text { - carrying out e-learning training to familiarize } \\
\text { employees with the codes of ethics; } \\
\text { - introducing Ethical Program Management } \\
\text { Systems; } \\
\text { - creating the position of the Agent for Ethics } \\
\text { and the Committee for Ethics; } \\
\text { - functioning of a helpline of the Code of } \\
\text { Conduct; } \\
\text { - organizing communication channels through } \\
\text { which unethical behavior can be reported; } \\
\text { - organizing workshops aimed at spreading } \\
\text { appropriate practices in business; } \\
\text { - functioning of websites devoted to ethics. }\end{array}$ & $\begin{array}{l}\text { - increasing the company's competitiveness, } \\
\text { strengthening its market position; } \\
\text { - shaping appropriate attitudes among } \\
\text { employees; } \\
\text { - an opportunity to detect a potential risk, } \\
\text { associated with the violation of ethical rules } \\
\text { or legal provisions or its minimization; } \\
\text { - achieving the desired atmosphere in the } \\
\text { organization; } \\
\text { - increasing management efficiency; } \\
\text { - creating a positive image of the company; } \\
\text { - disseminating the adopted ethical } \\
\text { principles in the enterprise; } \\
\text { - an opportunity to discuss ethical dilemmas. }\end{array}$ \\
\hline Management & $\begin{array}{l}\text { - introducing management systems in the field } \\
\text { of CSR and sustainable development; } \\
\text { - implementing the strategy of CSR and } \\
\text { sustainable development; } \\
\text { - conducting the analysis of CSR activities in } \\
\text { the context of the CSR strategy; } \\
\text { - training in the field of sustainable } \\
\text { development for employees; } \\
\text { - introducing the procedure for managing } \\
\text { conflicts of interests; } \\
\text { - appointing people and bodies responsible for } \\
\text { CSR and sustainable development (e.g. the } \\
\text { Board representative responsible for CSR, } \\
\text { The Committee of The Socially Responsible, } \\
\text { CSR Friends); } \\
\text { - cooperating with stakeholders in the } \\
\text { restructuring process; }\end{array}$ & $\begin{array}{l}\text { - improvement in environmental indicators } \\
\text { and the related parameters of manufacturing } \\
\text { and competitiveness; } \\
\text { - building relationships with customers; } \\
\text { - transparent principles of cooperation with } \\
\text { business partners; } \\
\text { - an opportunity to measure the effects of } \\
\text { actions taken within the framework of CSR } \\
\text { using the established measures of the } \\
\text { adopted CSR strategies; } \\
\text { - the basis for the preparation for reporting } \\
\text { non-financial data; } \\
\text { - an opportunity to clarify the tasks of } \\
\text { individual employees, departments or teams; } \\
\text { - an opportunity to get to know CSR } \\
\text { management methods by managers; } \\
\text { - an opportunity to discuss non-financial }\end{array}$ \\
\hline
\end{tabular}


- streamlining the processes and structures of the company in the context of CSR;

- introducing principles and regulations in order to ensure the balance between interests of entities involved in the company's operation;

- implementing socio-environmental policies aimed at reducing transactions constituting a threat to the natural environment.

\begin{tabular}{|c|c|c|}
\hline $\begin{array}{l}\text { A dialogue with } \\
\text { stakeholders }\end{array}$ & $\begin{array}{l}\text { - stakeholder maps with specific } \\
\text { communication forms; } \\
\text { - meetings and panels with stakeholders; } \\
\text { - meetings and a dialogue with experts; } \\
\text { - analyses of effectiveness and efficiency of } \\
\text { activities in the field of CSR; } \\
\text { - dialogue sessions; } \\
\text { - consulting the content of the Report of } \\
\text { sustainable development with the } \\
\text { environment; } \\
\text { - appointing different consultative and control } \\
\text { and advisory bodies (e.g. Council of } \\
\text { Stakeholders, Council of Customers); } \\
\text { - creativity-facilitation workshops; } \\
\text { - organizing Open Days }\end{array}$ & $\begin{array}{l}\text { - formulating recommendations and } \\
\text { expectations which are taken into account } \\
\text { while creating a new strategy concerning } \\
\text { CSR; } \\
\text { - acquiring information on the assessment of } \\
\text { the efficiency of CSR activities and their } \\
\text { impact on the perception of the brand by } \\
\text { stakeholders; } \\
\text { - obtaining expert recommendations and } \\
\text { suggestions in the area of sustainable } \\
\text { development; } \\
\text { - acquiring information on the expectations } \\
\text { of stakeholders and their opinion on the CSR } \\
\text { actions taken by entities and transferring it } \\
\text { directly to appropriate departments in } \\
\text { companies. }\end{array}$ \\
\hline Con & $\begin{array}{l}\text { - establishing and implementing the policies } \\
\text { of compliance, codes of conduct, compliance } \\
\text { management programs; } \\
\text { - creating the positions: chief compliance } \\
\text { officer, compliance officer; } \\
\text { - training and information campaigns; } \\
\text { - creating bookmarks in intranet, concerning } \\
\text { the principles for using compliance; } \\
\text { - formulating the policy relating to accepting } \\
\text { presents; } \\
\text { - developing brochures on compliance; } \\
\text { - creating educational programs on ethics and } \\
\text { compliance. }\end{array}$ & $\begin{array}{l}\text { - compatibility of the operations of the entity } \\
\text { with the law and internal principles; } \\
\text { - reducing the risk of unlawful conduct; } \\
\text { - an opportunity of effective non-compliance } \\
\text { risk management through defining, } \\
\text { monitoring, detecting and taking preventive } \\
\text { and corrective actions. }\end{array}$ \\
\hline
\end{tabular}

aspects of management of social responsibility in the enterprise.

The examples of practices presented in Table 2 give a general view on what types of activities are taken in individual categories. Obviously, each of the enterprises or organizations takes individual actions adequately to own operations in the area of CSR and sustainable development. Therefore, depending on the stage of involvement of the specific entity, they are more or less extensive and take into account the specificity of the activity conducted by the entity.

It should also be pinpointed that not only the implementation of new practices within the framework of CSR is a desired action. An important component of organizational governance is also the issue of evaluation, which is a part of the decision-making process. The evaluation relates in here to the ways of verification of the efficiency and effectiveness of the created structures and processes.

\section{Conclusion}

On the basis of the above considerations, it should be concluded that, among enterprises conducting their business activities in Poland, there is an increase in commitment associated with the implementation of good practices within the framework of CSR in the area of organizational governance. In the analyzed period, there were conducted very intensive operations in the field of as many as four out of five identified categories. Most good practices were implemented in the category of 'ethics'. It is a very favorable phenomenon since promoting and observing ethical 
behavior in business contributes to building trust both within the enterprise itself and good relationships with external stakeholders. There were also numerous practices undertaken for the benefit of three subsequent categories: management, a dialogue with stakeholders and reporting. On the other hand, within the framework of compliance, the implemented practices were not very numerous and, unfortunately, they did not indicate an increase.

The increasing involvement of enterprises in the implementation of good practices indicates the growing awareness of the role of socially responsible business management. Management staff are increasingly aware of the fact that such a way of conduct positively affects not only the broadly understood environment but it is also beneficial for the enterprise itself since socially responsible management influences creating a positive image of the company, which contributes to strengthening its market position and, consequently, has impact on financial results achieved by the enterprise.

The research undertaken in the paper is a starting point for further, more precise analysis of the implemented practices. It may refer to the analysis of good practices undertaken in the context of the size of enterprises, their ownership structure or type of activity. The results of the study can provide an answer to the question whether the instigated actions are in some cases forced by changing and demanding laws or are they the result of the adopted method of managing the enterprise.

\section{References}

Alexis, G. Y. (2010). Global Sullivan Principles. In Nevin Cohen (Ed.), Green Business: An A-to-Z Guide (Vol. 5). SAGE Publications.

Bednarowska, Z. (2015). Desk research - wykorzystanie potencjału danych zastanych w prowadzeniu badań marketingowych i społecznych. Marketing I Rynek, (7), 18-26.

Carroll, A. B. (1999). Corporate Social Responsibility. Evolution of Definitional Construct, Business \& Society, 38(3), 268-295.

Carroll, A. B., \& Shabana, K. M. (2010). The Business Case for Corporate Social Responsibility: A Review of Concepts, Research and Practice. International Journal of Management Reviews, 12(1), 85-105.

Commission of the European Communities. (2001). Green Paper: Promoting a European Framework for Corporate Social Responsibility, Brussels, DOC/01/9.

Dahlsrud, A. (2008). How Corporate Social Responsibility is Defined: an Analysis of 37 Definitions. Corporate Social Responsibility and Environmental Management, 15(1), 1-13.

European Commission. (2011a). Communication From The Commission To The European Parliament, The Council, The European Economic And Social Committee And The Committee Of The Regions: A renewed EU strategy 2011-14 for Corporate Social Responsibility, Brussels, COM(2011) 681.

European Commission. (2011b). Green Paper: The EU corporate governance framework. Brussels, COM(2011) 164.

Forum Odpowiedzialnego Biznesu. (2012). Raport: Odpowiedzialny biznes w Polsce 2011. Dobre praktyki, Warszawa.

Forum Odpowiedzialnego Biznesu. (2013). Raport: Odpowiedzialny biznes w Polsce 2012. Dobre praktyki, Warszawa.

Forum Odpowiedzialnego Biznesu. (2014). Raport: Odpowiedzialny biznes w Polsce 2013. Dobre praktyki, Warszawa.

Forum Odpowiedzialnego Biznesu. (2015). Raport: Odpowiedzialny biznes w Polsce 2014. Dobre praktyki, (2015), Warszawa.

Forum Odpowiedzialnego Biznesu. (2016). Raport: Odpowiedzialny biznes w Polsce 2015. Dobre praktyki, Warszawa.

Forum Odpowiedzialnego Biznesu. (2017). Raport: Odpowiedzialny biznes w Polsce 2016. Dobre praktyki, Warszawa.

Forum Odpowiedzialnego Biznesu. (2018). Raport: Odpowiedzialny biznes w Polsce 2017. Dobre praktyki, Warszawa.

Gustafson, J. (2007). Czym jest społeczna odpowiedzialność biznesu?. In Biznes 1 tom, Zarzadzanie firma (pp. 191-192). część 1, Biblioteka Gazety Wyborczej, PWN, Warszawa. 
Hermanson, D. R., \& Rittenberg, L. E. (2003). International Audit and Organizational Governance. In Bailey, A. D., Gramling, A. A., \& Ramamoorti, S. (Eds.), Research Opportunities in Internal Auditing (pp. 25-71). The Institute of Internal Auditors Research Foundation, Florida.

ISO/TMBG Technical Management Board - groups. (2010). ISO 26000:2010 Guidance on social responsibility.

Kuraś, P. (2011). Socially responsible investing as a new concept of investment. In A. Pabian (Ed.), Nowe kierunki, metody, techniki w zarządzaniu i marketing (pp. 557-572). Wydawnictwo Wydziału Zarządzania Politechniki Częstochowskiej, Częstochowa.

OECD. (2011). Guidelines for Multinational Enterprises. OECD Publishing.

OECD. (2015). G20/OECD Principles of Corporate Governance. OECD Report to G20 Finance Ministers and Central Bank Governors. OECD Publishing.

Steinmann, H. (1985). The Enterprise as a Political System. In Hopt, K. J., \& Teubner, G. (Eds.), Corporate Governance and Directors' Liabilities: Legal, Economic and Sociological Analyses on Corporate Social Responsibility (pp. 401-428). Walter de Gruyter, Berlin-New York.

The Caux Round Table. Principles for Business. Retrieved 20 December 2018, from http://www.cauxroundtable.org/index.cfm? menuid=8\#readhere

United Nations Global Compact. (2015). Guide To Corporate Sustainability. 